\title{
On the nesting biology of Pirhosigma Giordani Soika (Hymenoptera, Vespidae, Eumeninae), with special reference to the use of vegetable matter
}

\author{
Marcel G. Hermes ${ }^{1}$, Alexandre Somavilla² \& Bolívar R. Garcete-Barrett ${ }^{3}$
}

\begin{abstract}
${ }^{1}$ Laboratório de Sistemática e Biologia de Hymenoptera, Departamento de Biologia, Universidade Federal de Lavras, Caixa Postal 3037 , 37200-000 Lavras-MG, Brazil. marcelhermes@dbi.ufla.br

${ }^{2}$ Programa de Pós Graduação em Entomologia, Instituto Nacional de Pesquisas da Amazônia, Av. André Araújo 2936, 96060-001 Manaus-AM, Brazil.

${ }^{3}$ Laboratório de Biologia Comparada de Hymenoptera, Departamento de Zoologia, Universidade Federal do Paraná, Caixa Postal 19020, 81531-980 Curitiba-PR, Brazil.
\end{abstract}

\begin{abstract}
On the nesting biology of Pirhosigma Giordani Soika (Hymenoptera, Vespidae, Eumeninae), with special reference to the use of vegetable matter. The use of vegetable matter in nest building is not widespread among the Eumeninae, and is reported for the first time for the two species of potter wasps Pirhosigma superficiale and P. limpidum. These wasps make mostly spherical mud nests over which they attach small pieces of unmasticated plant matter. Use of plant fragments in this group of wasps is interpreted as camouflage behavior.
\end{abstract}

KEYWORDS. Eumenini; Insecta; nest construction; phylogeny.

Eumeninae, along with Euparagiinae and Stenogastrinae, is one of the least known subfamilies of Vespidae. Despite being the largest vespid subfamily, with more than 3,500 species described (Pickett \& Carpenter 2010), knowledge of eumenine biology is scarce and scattered throughout the literature over the past 200 years, compared to the Stenogastrinae, the Polistinae and the Vespinae, which comprise the eusocial vespid clade (Carpenter 1982; Pickett \& Carpenter 2010). The Eumeninae, however, are valuable for studies concerning the evolution of eusociality, since their behavior ranges from solitary to primitively social.

The morphological complexity of the Eumeninae has long prevented any attempt at a natural classification for the group (Parker 1966; Carpenter \& Cumming 1985). Until recently, no tribal classification has been widely adopted by the workers on the group, despite some proposals by early authors (e.g. Ashmead 1902). Hermes et al. (in press) have investigated the phylogenetic relationships among the main lineages of the Eumeninae, and proposed the first tribal division of the subfamily based on cladistic methods. As a result, three tribes were recognized and some biological extrapolations may be inferred, especially regarding nesting biology.

Species of Eumeninae may be classified into three types regarding nesting biology: excavators, renters and builders (Maindron 1882; Iwata 1976). These types are initially appealing for use in eumenine classification, but the behavioral plasticity observed for several species makes them polymorphic (Cooper 1979; Krombein 1979). The nest architecture of eumenines shows plasticity as well (Evans \& Matthews 1974), precluding that character from use in natural classification of the subfamily. However, the phylogenetic hypothesis recovered by Hermes et al. (in press) shows that a large clade of eumenine wasps (i.e. the tribe Eumenini) presents the elegant construction behavior of remarkable mud pots, lending the popular name "potter wasps", applied to the subfamily as a whole.

Pirhosigma Giordani Soika, 1978 is a small genus of solitary wasps composed of seven recognized species, all of them restricted to the Neotropical region. Few data have been ever published regarding the nesting biology of the species within this genus (Giordani Soika 1978), but it is widely accepted that all of them build mud pots as the remainder Eumenini. One record indicates that a species of Pirhosigma (identified as Pirhosigma sp.) nests in pre-existing cavities (Pires et al. 2012). This is perhaps an isolated record, which could indicate plasticity in the nesting behavior of this genus, such as observed for Pachodynerus de Saussure for example, but the possibility of wasp misidentification cannot be disregarded. The present work constitutes the first reliable biological information for species of Pirhosigma, namely $P$. superficiale (Fox, 1899) and P. limpidum Giordani Soika, 1978. This study also discusses the uncommon use of vegetable particles in the construction of the nest within members of the tribe Eumenini, which may help to understand the phylogenetic relationships among species of Pirhosigma and closely related eumenine genera.

The observations on P. superficiale were conducted in the countryside in the municipality of Santa Cruz do Sul (29 40'21'S and 52 $24^{\circ}$ '03”W), Rio Grande do Sul State, 
southern Brazil. Nest construction was observed during April 2007. The voucher specimen of the studied wasp is deposited in the Coleção Entomológica da Universidade de Santa Cruz do Sul (CESC) under the record number CESC 19920. Nests of $P$. limpidum were collected in the municipality of

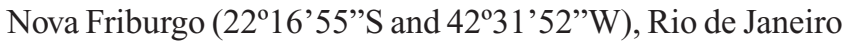
State, Brazil, on July 2007. Voucher specimens are deposited at the Universidade Federal de Lavras, Minas Gerais.

The female of $P$. superficiale built its nest with mud, attaching the cells to a human construction (Figs. 1-4). The nest consisted of two cells disposed laterally to each other; both cells remained exposed and had an average height of about 18 $\mathrm{mm}$. The cells were mostly rounded, but presented a conical protuberance on their lower portion, which probably is an artifact to aid in rainwater runoff, since the nest is susceptible to weather conditions. After the cells were completed, the wasp began flying back and forth from the nest; upon returning, the female wasp brought along small pieces of unmasticated vegetable matter. These vegetable particles were cut from a species of Poaceae, and were usually dry and longer than the nest height, being attached to the upper part of the cells and to the building wall (Fig. 4). The vegetable particles then covered the entire cells, possibly serving as a camouflage strategy by the wasp to avoid recognition by potential natural enemies. Jayakar \& Spurway (1965) suggested that Delta conoideum (Gmelin, 1790) (cited as Eumenes emarginatus conoideus) also camouflage the nests to prevent recognition of the cells by parasites. In this case, the wasp plastered (they used the term crépissage following Roubaud (1916)) the nest walls with additional lumps of mud which extended from the nest peak to the substrate on which it was constructed. A drawing presented by Maindron (1882: Pl. 1, figure 6) also suggested the use of extra mud on the cell walls to form an irregular surface.

The use of vegetable particles was also observed for $P$. limpidum. In this case, the construction of the nests was not observed, but the cells were collected and reared (Figs. 5 and $6)$. The female wasps attached the mud cells to a metal wire fence, which was then cut for nest removal. The cells were built separately, and we have no evidence whether they were built by the same female. Four nests were collected, and their diameter ranged from 10 to $12 \mathrm{~mm}$. The vegetable particles were dry and attached directly to the outer nest surface. After approximately 10 days, two males emerged from two different cells. One cell remained closed and no wasp emerged, and the other cell was already abandoned.

Giordani Soika (1978) examined one specimen of Pirhosigma deforme (Fox, 1899) from Villa Morra, Asuncion, Paraguay, collected by A.W. Bertoni that had a label attached, which we freely translate as follows: "its nest is semispherical, attached to tree trunks and covered with lichens, which perfectly camouflage it. It is about $9 \mathrm{~mm}$ long in diameter, its entrance is centric and without an apparent funnel shaped shelf".

Other species in the tribe Eumenini build mud pots (cells) that are adjacent to each other. The number of pots is variable, ranging from only one in several cases (e.g. species of Omicron de Saussure), or arranged in groups from two to four cells. In some cases, as in species of Hypodynerus de Saussure (Claude-Joseph 1930), Brachymenes Giordani Soika (Camillo 1999) (both placed in the tribe Odynerini) and Pachymenes de Saussure (M.G. Hermes, unpublished; another Eumenini), extra mud layers may be added to the cells in which cases the individual pots are no longer distinct. This condition may well serve as protection against potential enemies, but its homologous nature relative to the use of vegetable particles to camouflage the nests must be tested.

The use of vegetable matter in eumenine nest construction is not a new phenomenon for the subfamily as a whole. It seems that most species reported for the genus Zethus Fabricius incorporate leaf material into cell partitions. Species of Zethus (Zethoides) may construct their entire cells with masticated vegetable matter and resin, and the nests may be shared by several females tending their own brood (see Bohart \& Stange 1965 and references therein). Use of plant material may in fact characterize Zethini as a whole: Discoelius Latreille, Ischnocoelia Perkins and Protodiscoelius Dalla Torre also use vegetable matter for cell partition (van der Vecht \& Fisher 1972; Claude-Joseph 1930; van der Vecht 1981, respectively), and Psiliglossa Saunders and Raphiglossa Saunders use pith (van der Vecht \& Fisher 1972).

Pirhosigma was recovered in a large clade that contains only Neotropical taxa in the phylogenetic hypothesis presented by Hermes et al. (in press), along with several genera, among them Cyphomenes Giordani Soika and Pararhaphidoglossa von Schulthess. Besides their morphological similarity, biological information may serve as additional support for their close relationship. Cooper (2012) mentioned that the mandibles of Pararhaphidoglossa are shorter and more bristly than in other Eumenini, probably "adapted for the manipulation of vegetable fragments that are attached to the nest". More recently, Cooper (2013) described and illustrated the nests of three species of Pararhaphidoglossa (namely P. bicarinata Giordani Soika, P. confluenta (Fox) and P. imitatrix Giordani Soika), all of them being covered with vegetable particles. Bertoni (1918) reported the construction of a nest by a female of Cyphomenes anisitsii (Brèthes) (misidentified in that paper as Eumenes infernalis de Saussure) on the surface of trunks covered with lichen. Additional lichen particles were attached to the mud nest after construction, which perfectly camouflaged it.

The camouflage behavior using vegetable particles seems to have evolved three times independently in these three genera, as can be inferred based on our current knowledge of phylogenetic relationships (see fig. 83 in Hermes et al. in press). The role of camouflage in the nesting and reproductive success of these wasps is another question that prompts future investigations.

\section{ACKNOWLEDGEMENTS}

We thank Pedro R. Bartholomay for the pictures of $P$. superficiale and Paschoal C. Grossi for collecting the nests of $P$. limpidum, and James Carpenter for the critical reading of the manuscript. 

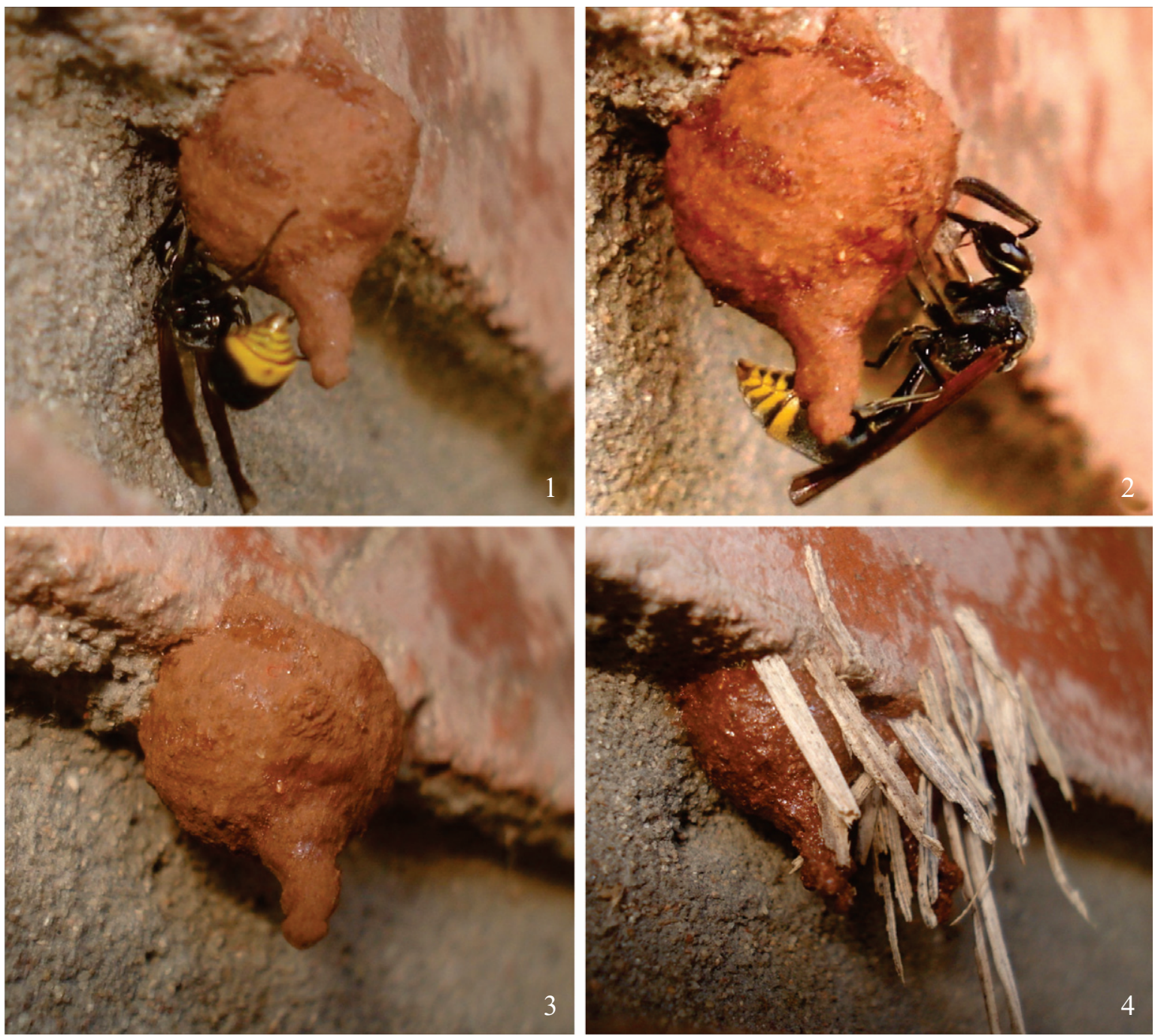

Figs. 1-4. Nests of Pirhosigma superficiale. 1-3, A single nest with a conical protuberance on its lower portion. 4, Two nests covered with vegetable matter.
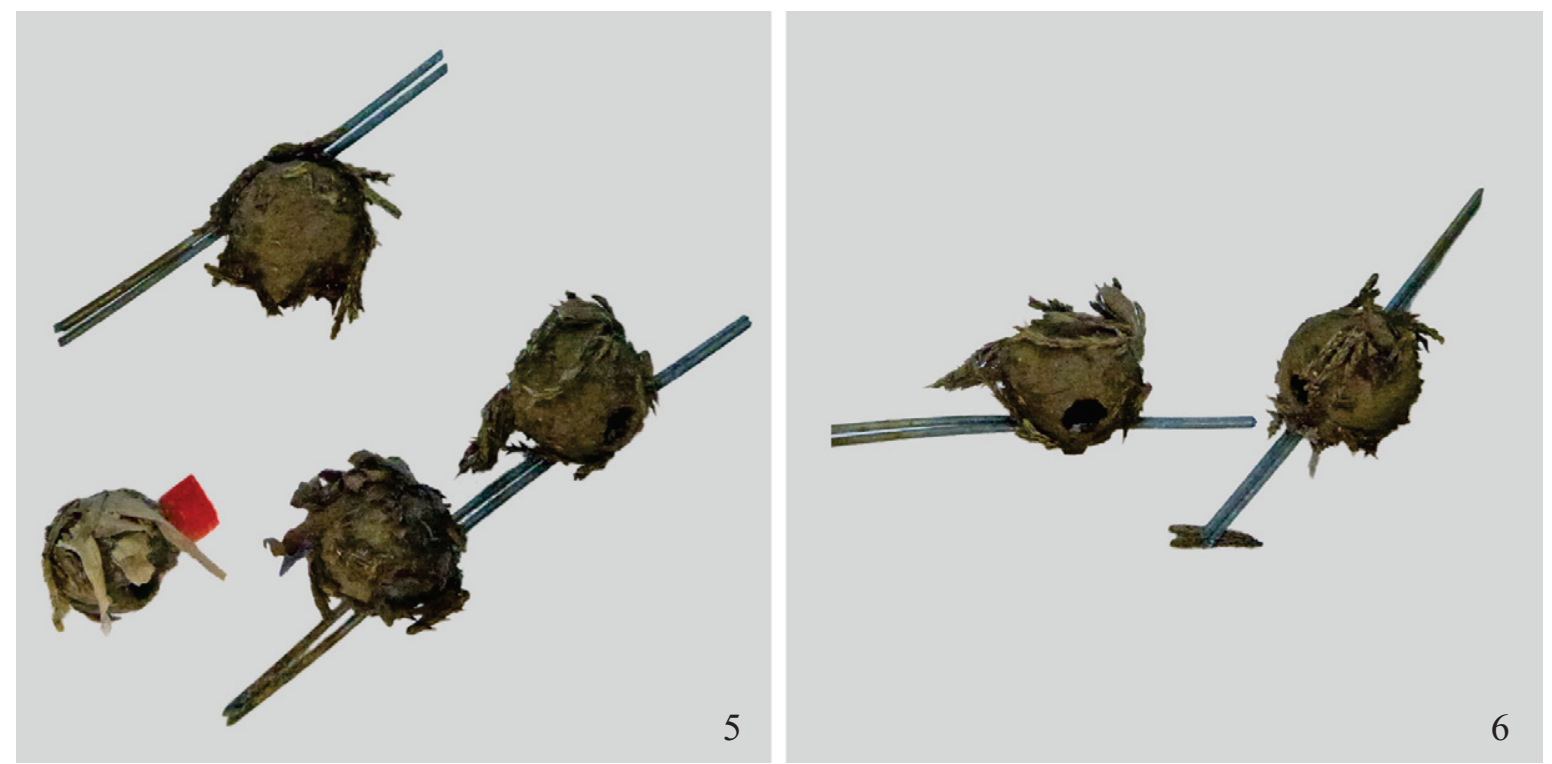

Figs. 5- 6. Nests of Pirhosigma limpidum built on a metal wire fence and covered with vegetable matter. 


\section{REFERENCES}

Ashmead, W.H. 1902. Classification of the fossorial, predacious and parasitic wasps, or the superfamily Vespoidea. The Canadian Entomologist 34: 203-210.

Bertoni, A. de W. 1918. Contribuición al conocimiento de los himenópteros diplópteros americanos (especies y nidos nuevos o pocos conocidos). Anales Científicos Paraguayos 2: 184-202.

Bohart, R.M. \& Stange, L.A. 1965. A revision of the genus Zethus Fabricius in the western hemisphere (Hymenoptera: Eumenidae). University of California Press Publications in Entomology 40: 1-208.

Camillo, E. 1999. A solitary mud-daubing wasp, Brachymenes dyscherus (Hymenoptera: Vespidae) from Brazil with evidence of a life-cycle polyphenism. Revista de Biología Tropical 47: 949-958.

Carpenter, J.M. 1982. The phylogenetic relationships and natural classification of the Vespoidea (Hymenoptera). Systematic Entomology 7: 11-38.

Carpenter, J.M. \& Cumming, J.M. 1985. A character analysis of the North American potter wasps (Hymenoptera: Vespidae; Eumeninae). Journal of Natural History 19: 877-916.

Claude-Joseph, F. 1930. Recherches biologiques sur les prédateurs du Chili. Annales des Sciences Naturelles (Zoologie) (10) 13: 235-254.

Cooper, K.W. 1979. Plasticity in nesting behavior of a renting wasp, and its evolutionary implications. Studies on eumenine wasps VIII (Hymenoptera, Aculeata). Journal of the Washington Academy of Sciences 69: 151-158.

Cooper, M. 2012. New species of Pararhaphidoglossa von Schulthess (Hymenoptera: Vespidae, Eumeninae): I, the mestiza and cressoniana groups. Entomologist's Monthly Magazine 148: 163-171.

Cooper, M. 2013. New species of Pararhaphidoglossa von Schulthess (Hymenoptera: Vespidae, Eumeninae): II, the confluenta group. Entomologist's Monthly Magazine 149: 79-91

Evans, H.E. \& Matthews, R.W. 1974. Notes on nests and prey of two species of ground-nesting Eumenidae from So. America (Hymenoptera). Entomological News 85: 149-153.

Giordani Soika, A. 1978. Revisione degli Eumenidi neotropicali appartenenti ai generi Eumenes Latr., Omicron (Sauss.), Pararhaphidoglossa Schulth. ed affini. Bolletino della Museo Civico di Storia Naturale di Venezia 29: $1-420$.
Hermes, M.G., Melo, G.A.R. \& Carpenter, J.M. in press. The higher-level phylogenetic relationships of the Eumeninae (Insecta, Hymenoptera, Vespidae), with emphasis on Eumenes sensu lato. Cladistics. doi: 10.1111/cla.12059.

Iwata, K. 1976. Evolution of Instinct: Comparative Ethology of Hymenoptera. New Delhi, Amerind Publishing Co., 535 p.

Jayakar, S.D. \& Spurway, H. 1965. Normal and abnormal nests of Eumenes emarginatus conoideus (Gmelin) including notes on crèpissage in this and other members of the genus (Vespoidea, Hymenoptera). Journal of the Bombay Natural History Society 62: 193-200.

Krombein, K.V. 1979. Vespoidea, p. 1469-1522. In: Krombein, K.V., Hurd Jr., P.D., Smith, D.R. \& Burks, B.D. (Orgs.). Catalog of Hymenoptera in America North of Mexico. Vol. 2. Washington, Smithsonian Institution Press.

Maindron, M. 1882. Histoire des guêpes solitaires (Euméniens de l'Archipel Indien et de la Nouvelle-Guinée). Considerations generalesnidification-moeurs etc. Annales de la Société Entomologique de France 2: $168-188$.

Parker, F.D. 1966. A revision of the North American species in the genus Leptochilus (Hymenoptera: Eumenidae). Miscellaneous Publications of the Entomological Society of America 5: 151-229.

Pickett, K.M. \& Carpenter, J.M. 2010. Simultaneous analysis and the origin of eusociality in the Vespidae (Insecta: Hymenoptera). Arthropod Systematics \& Phylogeny 68: 3-33.

Pires, E.P., Pompeu, D.C. \& Souza-Silva, M. 2012. Nidificação de vespas e abelhas solitárias (Hymenoptera: Aculeata) na Reserva Biológica Boqueirão, Ingaí, Minas Gerais. Bioscience Journal 28: 302311

Roubaud, E. 1916. Recherches biologiques sur les guêpes solitaires et sociales d'Afrique. La genèse de la vie sociale et l'évolution de 1 'instinct maternel chez les vespides. Annales des Sciences Naturelles (Zoologie) (10) 1: 1-160.

van der Vecht, J. 1981. On some Neotropical Eumenidae described by A. Ducke. Bolletino del Museo Civico di Storia Naturali di Venezia 31: $121-124$.

van der Vecht, J. \& Fischer, F.C.J. 1972. Hymenopterorum Catalogus, pars 8. Palaearctic Eumenidae. The Hague, Dr. W. Junk, 199 p.

Received 23 September 2013; accepted 17 November 2013

Associate Editor: Kevin A. Williams 